Ann. Biol. anim. Bioch. Biophys., I975, 15 (2), 385-386.

\title{
A PROGESTOGEN (CHLORMADINONE ACETATE $=$ CAP) FOR CYCLE CONTROL AND INFERTILITY TREATMENT IN THE MARE
}

\author{
K. ARBEITER and W. JÖCHLE \\ Department of Gynecology and Obstetrics, \\ Veterinary College, Vienna (Austria) \\ International Veterinary Section, \\ Syntex Research, Palo Alto (California)
}

Over the last six years, CAP has been used for infertility treatments and cycle control in mares in Austria. In all indications, the following treatment scheme was employed : 50 mg CAP suspension i. m. on Day I, followed by Io mg CAP pellets p. o. animal/day for Io days, from Day 2 through Day II.

I. Functional anestrus, with no recognizable ovarian functions during the season; mares barren for I to 4 years. Treatment during the second half of the season ; over the last four years, approximately 40 mares were treated annually.

More than 80 p. 100 of all mares showed heat within 7 to 9 days after medication, and ovulated; 45 p. Ioo conceptions resulted from service at the first heat.

2. Endometritis, at the conclusion of an antibacterial systemic and local treatment schedule, CAP was used routinely since 6 years to bring conception rates, known to be low after antibiotics alone (although biopsies and local inspection confirmed clinical cure), back to normal levels.

3. Cycle synchronization, during the spring season I974, I50 drought horses type mares (Prinzgauer) were treated regardless of their reproductive status. The goal was to get as many animals pregnant as possible at a given time with a minimum of pre-selection. 85 to 90 p. Ioo of all treated animals came in heat 7 to 9 days later, and $75 \mathrm{p}$. Ioo conceived at the first heat.

This confirms unpublished data by Meckenstock (1973) who used the same scheme in 30 cycling mares; he observed heat in all animals 9 to Io days after the treatment was terminated; 29 were bred, of which $2 \mathrm{I}$ (72.4 p. Ioo) conceived at the first heat. Eventually, 24 of those 29 bred (82.7 p. IOO) became pregnant. 


\section{RÉSUMÉ \\ CONTRÔLE DU CYCLE ET TRATTEMENT DE LA STÉRILITÉ CHEZ LA JUMENT AVEC UN PROGESTOGÈNE (ACÉTATE DE CHLORMADINONE = CAY)}

Chez la Jument, le traitement $50 \mathrm{mg}$ de CAP i. m., puis Io $\mathrm{mg} /$ jour pendant lo jours, permet :

- de provoquer les chaleurs chez plus de 80 p. Ioo des animaux et $45 \mathrm{p}$. Ioo de conception au premier ostrus chez les juments en anocstrus ;

- de ramener la fertilité à un taux normal chez les juments qui ont subi un traitement antibiotique pour endométrite :

- de synchroniser les chaleurs sur 2 jours chez les juments cycliques avec $75 \mathrm{p}$. roo de gestation au premier œstrus. 